\title{
Role of Transformative Capacity in River Basin Management Transformations
}

\section{Räsänen, Aleksi}

2019-01

Räsänen , A, Schönach , P , Jurgilevich , A, Heikkinen, M \& Juhola, S 2019 , ' Role of Transformative Capacity in River Basin Management Transformations ' , Water Resources Management , vol. 33 , no. 1 , pp. 303-317 . https://doi.org/10.1007/s11269-018-2103-5

http://hdl.handle.net/10138/296505

https://doi.org/10.1007/s11269-018-2103-5

acceptedVersion

Downloaded from Helda, University of Helsinki institutional repository.

This is an electronic reprint of the original article.

This reprint may differ from the original in pagination and typographic detail.

Please cite the original version. 


\section{Role of transformative capacity in river basin management transformations}

2 Aleksi Räsänen ${ }^{12 *}$, Paula Schönach ${ }^{1}$, Alexandra Jurgilevich ${ }^{1}$, Milja Heikkinen ${ }^{1}$, and Sirkku Juhola ${ }^{1}$

$3 \quad{ }^{1}$ Ecosystems and Environment Research Programme, Faculty of Biological and Environmental

4 Sciences, and Helsinki Institute of Sustainability Science (HELSUS), University of Helsinki, Helsinki,

$5 \quad$ Finland

$6 \quad{ }^{2}$ Department of Geography, Norwegian University of Science and Technology, Trondheim, Norway

7 *Corresponding author, aleksi.rasanen@helsinki.fi, ORCID: 0000-0002-3629-1837

\section{Acknowledgements}

10 This research was funded by Helsinki University Centre for Environment (HENVI) [project number 77255106], the Academy of Finland [grant 286676] and Tiina and Antti Herlin Foundation [Grant No. 20160025]. We thank Anja Nygren, Mira Käkönen, Adrián Monge Monge and Markku Kanninen for helping in the planning and carrying out the stakeholder scenario workshop.

\section{Highlights}

- $\quad$ Lack of studies analyzing transformative capacity in RBM in a multi-scale setting

- We analyzed transformations and transformative capacity in the River Vantaa basin, Finland

- Temporal analysis by examining earlier research, policy documents and a stakeholder workshop

- Three transformations can be identified that have steadily improved the water quality 


\section{Abstract}

25 To tackle problems related to water quantity and quality, transformations in water management systems have become of increasing interest. Transformative capacity can be defined as the ability first to adapt to changes, and if needed, to carry out fundamental changes in a specific system. Using a framework of ten components of transformative capacity and an analysis of earlier historical research, policy documents and data gathered in a stakeholder scenario workshop, we examine the relationship between past and future transformations and transformative capacity in river basin management in the River Vantaa basin, located in southern Finland. In the past, River Vantaa was heavily polluted by municipal wastewater.

The water quality has gradually improved but is still not considered good. The most successful changes have been concentrated on point source pollution, such as municipal wastewater, and they have mostly been driven by public administration and municipal coordination. In the future, more effort should be put on diffuse pollution, especially agricultural loading, and this requires changes in societal values and new forms of governance. We show how the past transformations have partly been driven by transformative capacity, but some transformations have enabled changes in the components of transformative capacity, indicating the interconnectedness of the different components. Furthermore, the interplay between transformations and transformative capacity occurs across spatial and temporal scales. We discuss how transformations take time, how transformative capacity evolves over longer time-spans, and how capacity and trajectories in local and wider scales are in a continuous interaction.

Keywords: river basin management; transformation; transformative capacity; water governance; water management; water quality 


\section{Introduction}

Multiple stressors, including increasing urbanization and population, land use changes and climate change, have influenced changes in the water quality and quantity patterns in various basin areas across the globe (Ferguson et al. 2013; Pahl-Wostl 2015; Abel et al. 2016; Gillon et al. 2016). Due to these changes, many have argued that transformations toward sustainability are needed in order to reduce the risks caused by unsatisfactory water quality, floods and droughts (Ferguson et al. 2013; Pahl-Wostl 2015).

55

Transformative capacity across governance levels is needed to achieve these transformations (Folke et al. 2010; Chaffin et al. 2016; Pahl-Wostl 2017; Wolfram et al. 2016). Transformative capacity is defined

"as the ability of a governance system to first adapt and, if required, transform structural elements as a response to current or anticipated changes in the social or natural environment" (Pahl-Wostl 2015, p. 27). So far, previous research on transformative capacity has focused, for example, on identifying its components (Wolfram 2016).

62

In river basin management $(\mathrm{RBM})$, past studies have identified transformations in the governance structures toward integrated basin-scale management and more inclusive governance (Daniell and Barreteau 2014; Abel et al. 2016; Jager et al. 2016). Specifically, the Water Framework Directive (WFD) has set ambitious goals for RBM and governance within the European Union. The WFD aims for "good ecological status" of European water bodies, and this should be achieved with participatory, basin-scale, governance. Currently, the results in achieving changes in the water quality and governance are mixed (Jager et al. 2016). In addition to these studies on transformations in RBM, there have been calls for 
transformative capacity is needed in achieving transformations, it is crucial to understand what transformative capacity is composed of and how its components interact with each other over time. Thus, the dynamics of capacity, actors and interactions between them are of a particular interest (Pahl-Wostl 2017). However, the research on transformative capacity has so far been limited (Chaffin et al. 2016). Furthermore, there is a lack of studies that analyze transformative capacity in RBM taking into account multi-scale interactions, and we address this gap.

We analyze the past 60 years and potential future changes in the water quality management in the River Vantaa basin, located in southern Finland. Although we concentrate on the river basin scale, we evaluate changes that have happened from local to international scales over time. By using Wolfram's (2016) framework and analysis of earlier historical research, policy documents and data gathered in a stakeholder scenario workshop, we examine the relationship between transformative capacity and transformations in the Vantaa RBM. We argue that previous literature about transformative capacity has merely speculated how transformative capacity is needed for transformations. We show how the relationship between transformations and transformative capacity is bidirectional and multi-scalar and that transformations themselves can trigger changes in capacity.

\section{River basin management and transformative capacity}

\subsection{Water governance and the issue of scale}

Water governance has become one of the prominent challenges in the past decades, aiming to balance between retaining water quality and quantity and satisfying societal needs, in the context of multi-scalar and multi-sectoral interests and management practices (Pahl-Wostl 2015, 2017). The need for sustainable 
water governance that is able to meet these demands and function in the above-mentioned environment is high (Pahl-Wostl 2017).

Water resources are governed at different scales, with local and transboundary approaches, such as the RBM. River basin approach to managing water resources has already been used for many decades, due to two reasons: (1) river basin being a natural and thus logical unit for water resources management, and (2) due to the multitude of purposes and stakeholders involved in river use (Downs et al. 1991, Newson 1997). RBM, being the cornerstone of integrated water resources management, suggests moving away from detached sectoral approaches toward incorporating those structures and processes that affect water quality and quantity. It also aims to reconcile approaches between the governmental and nongovernmental stakeholders, including industry, and those sectors that are not directly involved in the water management but are influenced by it (Heathcote 2009; Molle 2009). However, some scholars have voiced concerns about potential "local traps", arguing that re-scaling water governance from the (inter)national to local level may not necessarily result in empowering of local actors and more efficient governance (Norman and Bakker 2008).

\subsection{Transformations and transformative capacity}

Numerous definitions have emerged for transformations recently, and whilst some differences exist, most consider a transformation to be a fundamental change in a system, which involves multiple actors across scales (O’Brien 2012; Park et al. 2012). More recently, there has been specific interest in transformative change in water-related systems, e.g. at the basin level (Abel et al. 2016) or in urban water systems

(Ferguson et al. 2013). These studies highlight the complexity of these systems, as well as the necessity for change toward a more sustainable state. Furthermore, in order to achieve transformative change, we 
consider, similarly to Folke et al. (2010) that transformations in a system are enabled by transformative capacity.

121

122 Transformative capacity is closely linked to adaptive capacity but presupposes larger, systemic changes 123 (Pahl-Wostl 2017). Whereas adaptive capacity is defined as "the ability of a governance system to alter 124 processes and to adapt structural elements as a response to current or anticipated changes in the social or 125 natural environment", transformative capacity is defined as "the ability of a governance system to first 126 adapt and, if required, transform its structural elements" (Pahl-Wostl 2017, p. 5). The purpose of 127 developing such capacity is to enable and drive systemic change toward sustainability (Wolfram 2016).

128

129 In this study, we utilize the urban transformative capacity framework (Wolfram 2016), which is the most comprehensive typology of different components of transformative capacity (Table 1). In order to analyze transformations and capacity in a RBM system, we take into account the surrounding institutional context, identifying its comprising elements, governance structures and actors.

\section{Study area}

Our study is conducted in the context of River Vantaa that runs through the most densely populated and heavily utilized landscapes in Finland. The 100-km long river runs southward toward its mouth at the Gulf of Finland, approximately $8 \mathrm{~km}$ north of the city center of the country's capital, Helsinki. The basin of $1,685 \mathrm{~km}^{2}$ is distributed among fourteen municipalities with several rather small, and seven larger population centers. The river has a modest average flow of $16 \mathrm{~m}^{3} / \mathrm{s}$; however, due to small natural capacity to level changes in river flow, the extremes vary considerably. The upper reaches of the basin 
142

143

144

145

146

147

148

149

150

151

152

153

154

155

156

157

158

159

160

161

162

163

164

165

consist of mainly forest and agricultural land, while increasingly urbanizing areas dominate the southern parts of the basin (Räsänen et al. 2018).

River Vantaa has been concretely attached to the urbanity of Helsinki since 1876, when the city begun a municipal water supply, using the river as its fresh water source. The river's environmental state has been crucial to the capital, and water quality problems that have been reported since the 1930s. The deterioration of river water quality accelerated, especially during the post-WWII decades, when pollution due to industrial chemicals and nutrient surplus from the municipal wastewaters and run-offs from the intensifying agricultural activity changed the river's water composition. The river served as a natural outlet for upstream communities' wastewater, which increased steadily, due to population growth and the construction of sewers that concentrated the discharges into the river. By the end of the 1950s, poorly or entirely untreated wastewaters of more than fifty thousand people turned the river into an open sewer (Schönach 2007). River water quality was at its worst during the 1970s. Despite gradual recovery, the water quality is still not considered good, according to the EU WFD classification. This is primarily due to the nutrient leakage from agricultural lands, and other non-point sources, such as surface runoffs (Vahtera and Männynsalo 2018).

We argue that the River Vantaa basin is well suited as a case to explore transformative capacity, because (1) it is the example of a continuous and currently on-going urbanization of the river basin area, a process that is increasingly relevant on a global scale (Chin 2006); (2) despite its rather small size, River Vantaa is one of the most important rivers in the national context, due to its long-lasting interconnectedness to many societal functions, such as water supply and recreation, and; (3) the most important and active stakeholders in the river basin management act within the urban context. Thus, this case also aligns with Wolfram's (2016) framework, which applies a broad understanding of 'urban', including a strictly urban 
setting, and also places in an urban context or having implications for the city. For the purpose of this study, we study transformations related to water quality, affected by diffuse and point source pollution over a period, ranging from the 1950s to the future.

\section{Methods}

Since we investigated transformations and related capacity along a long temporal trajectory, we applied multiple methods to analyze past and future oriented transformations. First, to evaluate past trends in the River Vantaa basin, our analysis consisted of five steps: (i) review of existing publications, (ii) identification and selection of three key transformations, (iii) analysis of the transformations with the help of existing publications and additional data sources, (iv) identification of the components of transformative capacity, and (v) assessment what components of transformative capacity were linked to each transformation and other components. Second, we analyzed data gathered in a stakeholder scenario workshop to sketch potential future transformations and capacity that is needed for transformations.

The history of the River Vantaa management has been recorded extensively, and existing publications provide a valid synthesis of the historical changes of the river and its basin (Herranen 2001; Rahikainen 2001; Schönach 2007, 2015; Juuti 2015; Heikkinen et al. 2016). These studies are based on a diverse set of historical sources, which are referenced in detail in the respective publications. The sources include primary, archival documents, policy documents, and media material. We leaned on these studies, and based on their findings, we first constructed a narrative of the historical changes in the River Vantaa basin. Furthermore, three transformations were identified and selected for closer scrutiny. The transformations (problem awareness, detachment, overflow) could be loosely dated along three key temporal phases, although they comprised of both diverse, interlinked, and context-bound trajectories, 
and single events, which were of importance in the transformations. Additional sources for the analysis of the identified key phases were gathered in a heuristic process (see e.g. Berg 2009, pp. 301-303; Winiwarter and Knoll 2007, pp. 78-80).

In order to identify the components of transformative capacity, and to analyze their interaction with each other, we drew on Wolfram's (2016, p. 126) description of transformative capacity as “a qualitative measure for an emergent property that reflects attributes of [..] stakeholders, their interactions, and the context they are embedded in." In our qualitative content analysis of the material (e.g. Cresswell 2014), we utilized altogether up to 60 factors that indicated and specified different components of transformative capacity (C1-C10), as presented by Wolfram (2016). Our first round of analysis revealed that the identified components of transformative capacity were connected to the culmination events of the transformations in a variety of ways. To better understand the role and qualitative characteristics of these components, we then conducted another round of analysis, in which we filtered components that were linked to each transformation and explored how the components themselves were connected to other components of transformative capacity.

In addition to the analysis of past transformative capacity, we examined possible futures and desired future transformations in the River Vantaa basin with the help of data gathered during a one-day stakeholder scenario workshop on 2 September 2015. It has been argued that stakeholder scenario workshops are particularly useful in building future scenarios, as well as sharing views and knowledge (Priess and Hauck 2014). Twenty key stakeholders from different levels of administration, academia and civil-society organizations participated in the workshop. We invited stakeholders, who have had longterm experience of the river and who represented various stakeholder groups, including environmental administration, municipal and regional planning, as well as agricultural, environmental and residential 
214 organizations. In small groups of 4-6, the participants (1) discussed the major changes in the basin during 215 the past 30 years, (2) voted for the most important drivers of change in the next 30 years, (3) built 216 narratives of four different future scenarios, of which directions were chosen by the workshop organizers, 217 (4) drew potential land use and water management changes in each of the scenarios on a map of current 218 land use, (5) sketched strategies on how the most desirable future could be achieved, and (6) identified barriers that inhibit the scenario to happen (see Räsänen et al. 2017 for more detailed description of the workshop). The data gathered in the workshop was used to consider future changes in the basin but some of the data was also utilized in the historical analysis. From the data, the components of transformative capacity were analyzed using qualitative content analysis (Cresswell 2014).

\section{Results}

\subsection{Past transformations at River Vantaa}

\subsubsection{Transformation 1 (T1): Awareness transformation}

In the first transformation, awakening to the poor water quality initiated municipal coordination and improvement in municipal wastewater treatment (Fig. 1). The gradual deterioration of the water quality in River Vantaa was a growing concern, especially since it was the source of water supply of the City of Helsinki. The concern culminated during the 1950s (Schönach 2015). Chemicals, especially phenols, increasingly polluted the river, and caused a repulsive taste in the tap water in Helsinki, caused by reactions of pollutants with water purifying substances. These problems drew national attention, and the

Office of the Chancellor of Justice and the Central Criminal Police began investigations into the culprits in 1958 (Juuti 2015). Furthermore, an unprecedented algal bloom of a particularly obnoxious 
cyanobacteria occurred in the upstream parts of the river in late summer of 1959. While the purified tap water was safe for use, there was a strong taste and smell of mold in the water. Moreover, multiple use of water for cooking, washing and watering, spread the repulsive smell all over the capital (Rahikainen 2001; Schönach 2007). These critical events triggered broader acknowledgement and understanding of the vulnerability of the riverine ecosystem to the anthropogenic discharges and the long-lasting negative effects that the past pollution caused in the system (C4).

In addition to the local events, the national Water Protection Committee recommended an intensification of water protection activities and cooperation with voluntary-based, regional associations in its report (Vesistönsuojelukomitea 1958), and the Water Protection Association of the River Vantaa and Helsinki Region was eventually founded in 1963. With all the municipalities of the basin and several communities and industrial establishments as members, the Association became an intermediary organization that has since its foundation contributed to the diversity of actors involved in the RBM (C1). The leaders of the Helsinki Waterworks have especially been influential and active proponents of the activities within the Association (C2) (Schönach 2007). The Association has also developed into an important actor in knowledge production about the river basin and its condition (C5). Concrete cooperation between the municipalities to protect the river water from further pollution was realized in 1960, when the construction of a wastewater treatment facility became topical in the municipality of Vantaa, just north of Helsinki. Instead of investing in own treatment facilities in Vantaa, the two municipalities agreed on an alternative solution $(\mathrm{C} 5, \mathrm{C} 10)$. The wastewater was redirected via transfer pipes to a treatment plant in Helsinki. As this plant discharged directly to the Gulf of Finland, the river was thus spared from additional wastewater loads. The following year, the township of Kerava also followed this arrangement (Schönach 2007). In general, the national legislative developments influenced the increasing emphasis 
262

263

264

265

266

267

268

269

270

271

272

273

274

275

276

277

278

279

280

281

282

283

284

285

into effect in 1962, Helsinki established a municipal Board of Water with the aim to prevent the pollution of River Vantaa (C7) (Schönach 2007).

\subsubsection{Transformation 2 (T2): River detachment from water supply and sewerage}

In the second transformation, improvement in water quality and a detachment from water supply allowed considerations of river multi-functionality (Fig. 1). The above discussed new water legislation was an important milestone that influenced Finnish wastewater treatment in the long run (C10). The law imposed effective wastewater treatment, even though the implementation of it was at first sluggish, due to exceptions granted to municipalities (Katko 1997). During the following decades, more population centers were attached to the sewage systems within the river basin, and investments in the wastewater purification capacity increased (C7). Most importantly, the trend of diverting wastewaters away from the river through municipal cooperation was extended (C10) (Herranen 2001; Schönach 2007). As highlighted by the workshop participants, increasing investments in technological facilities, such as pumping stations and transfer sewers, were crucial in enabling a reduction of wastewater discharges into the river and thus, its gradual recovery from its degraded state $(\mathrm{C} 7)$. On the other hand, the costly wastewater treatment and other pollution abatement measures have been subject to a constant debate about priorities in the municipal investments, and the lack of sufficient resources has been highlighted throughout the different phases (Vantaanjoki-toimikunta 1985; Schönach 2015).

Regional cooperation and close links between the governance regime and the technological arrangement have played a strong role in the River Vantaa RBM. A federation of municipalities, formed in 1976, has also been an important transboundary organization tasked with the promotion of sanitation and water protection issues at the regional level (C1, C2) (Herranen 2001). It has been a key actor in implementing 
national policies at the regional level, and with its resources (C7) and mandate for coordinative leadership

287 (C2) has contributed significantly to the local level sustainability transformation (C10).

288

In 1982, River Vantaa was detached from the fresh water supply of Helsinki, when an aqueduct from a more distant Lake Päijänne was completed, after more than a decade of planning and construction (Herranen 2001). This meant the beginning of a new era in the management of the river (Schönach 2015). As a result, alternative, recreationally motivated, collective visions of the river's future emerged (C5). The slowly recovering former sewage outlet became a subject of intensive planning (see e.g. Vantaanjoki-toimikunta 1985; Helsingin kaupunki 1988), with new stakeholders, such as NGOs, and new initiatives for broader public participation to be involved (C1, C3, C5). Local, participatory restorative projects were launched, for instance, at the Lake Tuusulanjärvi, which was severely eutrophicated (C9, C10) (Hietala 2017). Considerable new funding (C7) flowed into projects, such as

fishway construction and the restoration of rapids for fishery (Haikonen et al. 2013). Facilities for canoeing and swimming improved and the river banks became popular recreational areas (see e.g. VHVSY 2017). These developments contributed to a more pronounced understanding and recognition of the ecological value of the river valley $(\mathrm{C} 4)$, highlighted by the 17 areas that form a part of the PanEuropean Natura 2000 network. There was an increasing importance of the river basin as a broadly valued environmental asset, both locally and also extending further in the urbanizing region (C5, C9, C10).

\subsubsection{Transformation 3 (T3): Wastewater overflow transformation}

In the third transformation, a concern over wastewater overflows led to a new form of co-operation (Fig. 1). The water quality in the river has improved significantly since its worst days, and the wastewater 
treatment is considered efficient in general. However, periodic wastewater overflows have developed

311 into a contested, socio-technical problem during the last decades. For example, abnormal summer

312 flooding caused large scale wastewater emissions in 2004 (Saura et al. 2005; Vahtera et al. 2005;

313 Heikkinen et al. 2016). Stakeholders have had varied interpretations of the role of wastewater overflows

314 in terms of damages to the river ecosystem. However, they still regarded the overflows and the 315 wastewater a continued source of pollution (Heikkinen et al. 2016).

The public debates have become polarized between those claiming that the overflows should be completely prevented, and those claiming that there is no realistic opportunity to reach that goal (Heikkinen et al. 2016). In 2013, the representatives of the wastewater treatments plants (WWTPs) announced that their new goal is to reach a situation in which all the overflows can be prevented $(\mathrm{C} 2)$, and this united the stakeholders behind the same goal (C5) (Heikkinen et al. 2016). A new cooperative meeting system was created in the same year $(\mathrm{C} 1, \mathrm{C} 3)$ to increase and improve the communication between NGOs, WWTP representatives and other stakeholders. It seems that while the annual meetings have brought the stakeholders' views closer to each other, a lack of concrete planning might hamper a discernible change in the near future (Heikkinen et al. 2016). As the transformation of overflow management is currently on-going, it is too early to make definite conclusions about the resulting role of transformative capacity and the actual realization of transformative change.

\subsection{Transformations in the future}

In the past, water quality management efforts to tackle point source pollution have been more successful than curbing diffuse loads in the River Vantaa RBM. In the future, the reduction efforts need to be 
334 populated areas and urban storm water (Fig. 1). During 2011-2016, 47\% of the nitrogen load was caused 335 by agriculture, $27 \%$ by background (natural) loading and $15 \%$ by point source loading, whereas main 336 phosphorus sources were agriculture (57\%), sparsely populated areas (21\%) and natural loading (14\%)

337 (Vahtera and Männynsalo 2018). Participants in the workshop considered an increase in the coverage of 338 urban area and changes in the agricultural management practices as the most important drivers of change in the future. This calls for changes in the RBM and different components of transformative capacity need to be mobilized and strengthened.

342 Stakeholders expressed a preference for a radical transformation toward sustainability, but they 343 considered that it is more plausible that shifts continue to be modest in the future. In terms of transformative capacity, participants desired for more inclusive and participatory governance in the river basin to include various actors in the decision processes (C1), changes in values and a collective vision toward a greener future (C5), increase in experimentation to promote more sustainable agricultural practices (C6), work across the administrative levels, and a reinforcement of the basin-scale governance (C10). It was considered that the EU WFD is one of the drivers in the governance shifts and acknowledged that the current governmental system, societal values and economic priorities inhibit further improvement in the water quality management. For instance, according to the recent policy document (Karonen et al. 2015), there have only been modest funds for environmental measures in agriculture, and only part of the suggested measures are implemented.

\subsection{Transformative capacity component connections to transformations and other components}

In the Vantaa RBM, two different types of connections between transformations and transformative 
while transformation 2 acted as a trigger that initiated changes in various components of transformative capacity. Apart from the connections between capacity and transformations, there are also connections between different components of transformative capacity (Table 2). For instance, according to our analysis, the increased awareness of vulnerability of the River Vantaa ecosystem (i.e. transformation 1) was a change in component 4 , which acted as a driver for changes in other components.

\section{Discussion and conclusions}

Our findings show that the role of transformative capacity in transformations is not just about driving changes. Instead, transformations and transformative capacity are in a multidimensional relationship across spatial, administrative and temporal scales. Transformative changes are enabled not only by capacity, but also by the overall changes in the societal, political and socio-economic context over time. Furthermore, the capacity itself is formed and influenced by such changes. Next, we will discuss in more detail the relationship between transformative capacity and transformations.

Previously, it has been argued that forced transformation is more likely to be initiated at a larger scale than the focal scale (Folke et al. 2010). In the River Vantaa RBM, many of the changes have been driven by changes in larger scale governance structures, most prominently by the enforcement of the national Water Act in 1962 and the EU-wide WFD in 2000. Both triggered changes in various components of transformative capacity, which in turn drove regional and local changes in the management of river basin and water resources. The Water Act was the main driver for the eventual build-up of wastewater treatment infrastructure, and the WFD has been the key pressure for more inclusive governance at River Vantaa (cf. Jager et al. 2016), which according to the stakeholder perspectives, has been instrumental in achieving more sustainable RBM. 
383 Currently, a wide set of actors are included in RBM, and there is basin-scale coordination on many issues.

384 However, our long-term analysis also shows that the governance structure had gone through significant 385 changes well before the WFD, and that these legislative changes have only been one part of the enabling 386 factors of transformations. At River Vantaa, the capacity for intercommunal cooperation and working across the geographical levels in the form of joint investments have significantly decreased pollution levels in the river. Thus, our case supports the perception of bridging political-administrative levels as crucial in RBM and water governance (Daniell and Barreteau 2014; Pahl-Wostl 2017). This is particularly noteworthy in Finland, where traditionally strong municipal autonomy challenges cooperation (Joas 2001). However, while there are evident benefits of the basin scale governance for the sustainability transformations, the potential emergence of new problems in institutional interplays and complexity, power relations and value conflicts should be addressed carefully (e.g. Wallis \& Ison 2011;

Daniell and Barreteau 2014; Abel et al. 2016; Jager et al. 2016).

Another prominent transformative change in the River Vantaa RBM was the construction of the Päijänne aqueduct in 1982 (Transformation 2), which freed the river from its previous function as the primary water supplier to Helsinki metropolitan area and changed how water resources are managed in the basin. The aqueduct construction was driven by the need to develop the capital's water security, and it ended 400 up being a mobilizer of capacity. It was thus a smaller scale transformation inside RBM, but it initiated changes in the whole RBM (see Folke et al. 2010). As long as the utilization of the river was clearly dominated by the critical water supply function and its technocratic management, the alternative visions for the future of the river, including outlooks emerging from the community, were limited. The functional 404 detachment of the river from the urban water supply shifted the former balance of coexistence between 405 strong, single-issue-driven leadership (Waterworks) and more inclusive, collaborative governance of a 
multi-functional river toward the latter. These mobilized and changed components of capacity again 407 affected the governance regime and the entire RBM.

408

409 Our analysis reveals that certain critical events act as triggers for mobilizing latent capacity for the future 410 transformative change. The accelerating river degradation culminated in the critical years characterized 411 by the episodes of infamous river pollution around the late 1950s and marked the reach of a critical 412 threshold, where the river system could not satisfactorily serve as the capital's main water supply anymore (Transformation 1) (cf. Chaffin et al. 2016). Similarly, half a century later, the abrupt and obnoxious wastewater overflow episodes proved to be momentous events that threatened the ecological and recreational values of the river, and triggered the mobilization of dormant, yet existing capacity (Transformation 3). Next to the typically occurring, immediate, post-crises public and political awareness and pressure, a mobilization and strengthening of capacity to strive for transformative change in the critical conditions, revealed by the crises, could be observed (Chaffin et al. 2016). The components of transformative capacity were not generated through the critical events, but components that have builtup over longer time are actualized in the wake of these critical events. New priorities in the allocation of municipal resources enabled the investments in sanitary infrastructure and facilitated the creation of intercommunal cooperative solutions and new arenas for broader-based deliberation and participatory possibilities.

Our findings show an overall increase in transformative capacity over time. Shifting emphasis of the different components of transformative capacity in relation to transformations can also be observed, which supports the perception of transformative capacity not as static (Coleman and Chiasson 2002), but 428 fluctuating and mobilized in different contexts. The case also reveals the significance of financial 429 resources as capacity for transformative change, which however, over our long time span investigation 
have evoked contradicting perceptions (see also Pahl-Wostl 2015). While the wastewater investments

431 have enabled transformative changes in the wastewater system attached to the river, at the same time, the lack of sufficient funding has been perceived as one of the single most important factor preventing further transformative change.

Similarly, while increasing capacity to an inclusive governance regime can be observed, present day

stakeholders consider more inclusivity and participatory modes of action necessary to reach future sustainability transformations. This is particularly significant, as further improvement in river water quality can only be achieved through effectively decreasing diffuse pollution (Vahtera and Männynsalo 2018). Since reducing point source pollution has been more successful in the past, a shift toward curbing diffuse pollution is necessary, which in turn requires active involvement of all levels, including individuals and farmers (Wright and Jacobsen 2011; Wardropper et al. 2015; Gillon et al. 2016), and possibly a new balance between top-down and bottom-up governance processes (Pahl-Wostl 2017). Similar challenges have been evident also in other river basins, such as Yahara in Wisconsin, USA, where there has been no significant reduction in phosphorus loading, despite continuous effort (Wardropper et

al. 2015; Gillon et al. 2016). Although there are similarities between river basins across the world, a direct comparison is challenging due to context-specficity of historical trends and main drivers of change (cf. Räsänen et al. 2017, 2018).

Our analysis highlights how past transformations have (1) decreased point-source loading, (2) increased multi-functionality of the river basin and water resources, and (3) gradually improved water quality. However, our analysis also shows how there is a need for changes in transformative capacity, partly because the basin areas and societies are continuously changing. In managing water quality, the drivers 
454 changes in RBM (Godden et al. 2011; Gillon et al. 2016). The long temporal horizon of our study also 455 reveals a shifting emphasis in dominant uses of the river, thus influencing the goal setting for RBM. 456 Furthermore, societal values also change over time and shifts in the values imply new requirements on 457 societally accepted and desired ways of RBM (Méthot et al. 2015).

458

Although the transformative capacity framework (Wolfram 2016) was originally developed for the urban 460 context, our study shows that it is applicable for other settings as well. In comparison to strictly urban contexts, the river basins potentially cover large geographical areas, include a variety of land uses and are often divided into a multitude of administrative areas and levels. In river basins, the importance and challenge of transformative capacity to function across the horizontal and vertical political-administrative levels is pronounced. Furthermore, we show how capacity cannot be treated in an isolated manner; instead, it should be linked to broader societal developments over long time scales. There is an evident multidimensional relationship between the capacity and transformations, which evolves over time. However, we could only touch on how transformations and capacity interact across the spatial and temporal scales, and these questions should be addressed in future research.

Conflict of Interest - None

\section{References}

Abel N, Wise RM, Colloff MJ, Walker BH, Butler JRA, Ryan P, Norman C, Langston A, Anderies JM, one is in charge": insights from Australia's Murray-Darling Basin. Ecol Soc 21(2): 23 
477 Berg BL (2009) Qualitative research methods for the social sciences. 7th edition. Pearson Allyn and 478 Bacon, Boston

479 Chaffin BC, Garmestani AC, Gunderson LH, Benson MH, Angeler DG, Arnold CA, Cosens B, Craig 480 RK, Ruhl JB, Allen CR (2016) Transformative environmental governance. Annu Rev Env Resour 41: $481 \quad 399-423$

482 Chin A (2006) Urban transformation of river landscapes in a global context. Geomorphology 79(3): 460$483 \quad 487$

484 Coleman WD, Chiasson C (2002) State power, transformative capacity and adapting to globalization: an 485 analysis of French agricultural policy, 1960-2000. J Eur Public Policy 9(2): 168-185

486 Cresswell JW (2014) Research design: qualitative, quantitative, and mixed methods approaches, 4th 487 edition. Sage Publications, Thousand Oaks

Daniell KA, Barreteau O (2014) Water governance across competing scales: coupling land and water management. J Hydrol 519: 2367-2380

Downs P, Gregory K, Brookes A (1991) How integrated is river basin management? Environ Manage 491 15(3): 299-309

Ferguson B, Brown R, Deletic A (2013) A diagnostic procedure for transformative change based on 493 transitions, resilience, and institutional thinking. Ecol Soc 18(4): 57

494 Folke C, Carpenter SR, Walker B, Scheffer M, Chapin T, Rockstrom J (2010) Resilience thinking: 495 integrating resilience, adaptability and transformability. Ecol Soc 15(4): 20

Gillon S, Booth EG, Rissman AR (2016) Shifting drivers and static baselines in environmental 497 governance: challenges for improving and proving water quality outcomes. Reg Environ Chang 16(3): 759-775

499 Godden L, Ison RL, Wallis PJ (2011) Water governance in a climate change world: appraising systemic 500 and adaptive effectiveness. Water Resour Manag 25(15): 3971-3976 
501 Haikonen A, Paasivirta L, Helminen J, Tolvanen O (2013) Vantaanjoen yhteistarkkailu - Kalasto ja 502 pohjaeläimet vuonna 2012. Kala- ja vesitutkimus Oy, Kala- ja vesitutkimuksia nro 105, Klaukkala

503 Heathcote IW (2009) Integrated watershed management: principles and practice, 2nd Edition. John 504 Wiley, New York

505 Heikkinen M, Schönach P, Massa I (2016) Politicization of wastewater overflows: the case of the Vantaa 506 River, Finland. Water Policy 18(6): 1454-1472

507 Helsingin kaupunki (1988) Vantaanjoki - pääkaupungin kehdosta virkistyksen valtasuoneksi: 508 toimenpideohjelma (1987-88) 1989-1993. Helsingin kaupungin johtajistotoimikunta, Working group 509 report, Helsinki

510 Herranen T (2001) Vettä ja elämää: Helsingin vesihuollon historia 1876-2001. Helsingin Vesi, Helsinki 511 Hietala J (ed.) (2017) Tuusulanjärven kunnostus vuosina 1999-2013: Hoitotoimia ja seurantaa. 512 Uudenmaan elinkeino-, liikenne- ja ympäristökeskus, Report 56/2017, Helsinki

513 Jager NW, Challies E, Kochskämper E et al (2016) Transforming European water governance? 514 Participation and river basin management under the EU water framework directive in 13 member states. 515 Water 8(4): 156

516 Joas M (2001) Reflexive modernisation of the environmental administration in Finland: essays of 517 institutional and policy change within the Finnish national and local environmental administration. Åbo 518 Akademi University Press, Turku

519 Juuti P (2015) Valkea kaupunki, mustat vedet: Helsingin vedet 1800-luvun lopusta 2000-luvulle. 520 Tampere University Press, Tampere

521 Karonen M, Mäntykoski A, Lankiniemi V, Nylander E, Lehto K, Jalava L (eds) (2015) Uudenmaan 522 vesienhoidon toimenpideohjelma vuosille 2016 - 2021. Uudenmaan elinkeino-, liikenne- ja 523 ympäristökeskus, Raportteja 134 / 2015, Helsinki 
524 Katko T (1997) Water!: evolution of water supply and sanitation in Finland from the mid-1800s to 2000.

525 Finnish Water and Wastewater Works Association, Helsinki

526 Méthot J, Huang X, Grover H (2015) Demographics and societal values as drivers of change in the Great

527 Lakes-St. Lawrence River basin. J Great Lakes Res 41: 30-44

528 Molle F (2009) River-basin planning and management: The social life of a concept. Geoforum 40(3):

$529 \quad 484-494$

530 Newson M (1997) Land, water and development: sustainable management of river basin systems.

531 Routledge, London

532 Norman E, Bakker K (2009) Transgressing Scales: Water Governance Across the Canada-U.S.

533 Borderland. Ann Assoc Am Geogr 99(1)

534 O’Brien K (2012) Global environmental change II From adaptation to deliberate transformation. Prog 535 Hum Geogr 36(5): 667-676

536 Pahl-Wostl C (2015) Water Governance in the Face of Global Change: From Understanding to 537 Transformation. Springer, Cham

538 Pahl-Wostl C (2017) An evolutionary perspective on water governance: from understanding to 539 transformation. Water Resour Manag 31(10): 2917-2932

540 Park SE, Marshall NA, Jakku E, Dowd AM, Howden SM, Mendham E, Fleming A (2012) Informing 541 adaptation responses to climate change through theories of transformation. Glob Environ Chang 22(1):

$542 \quad 115-126$

543 Priess JA, Hauck J (2014) Integrative scenario development. Ecol Soc 19(1): 12

544 Rahikainen E (2001) Kuohuva vuosisata: Vantaanjoki ja helsingin vedenotto. In: Laakkonen S, Laurila 545 S, Kansanen P, Schulman H (eds). Näkökulmia helsingin ympäristöhistoriaan: Kaupungin ja ympäristön 546 muutos 1800- ja 1900-luvuilla. Helsingin kaupungin tietokeskus, Helsinki, Finland, pp 206-225 
547 Räsänen A, Juhola S, Monge Monge A, Käkönen M, Kanninen M, Nygren A (2017) Identifying

548 mismatches between institutional perceptions of water-related risk drivers and water management 549 strategies in three river basin areas. J Hydrol 550: 704-715.

550 Räsänen A, Nygren A, Monge Monge A, Käkönen M, Kanninen M, Juhola S (2018) From divide to 551 nexus: Interconnected land use and water management changes shaping risks and vulnerabilities. Appl 552 Geogr 90C: 106-114.

553 Saura A, Könönen K, Yrjölä R, Rinne J (2005) Vantaanjoen yhteistarkkailu kalasto vuonna 2004 ja 554 pohjaeläimet vuosina 2002-2004. Finnish Game and Fisheries Research Institute, Kala- ja 555 riistaraportteja nro 368, Helsinki

556 Schönach P (2007) Vantaanjoen suojeluyhteistyö toisen maailmansodan jälkeen. Historiallinen 557 aikakauskirja 105(1): 22-33

558 Schönach P (2015) Expanding Sanitary Infrastructure and the Shaping of River History: River Vantaa 559 (Finland), 1876-1982. Environ Hist 21(2): 201-226

560 Vahtera H, Muukkonen P, Männynsalo J, Lahti K (2005) Vantaanjoen yhteistarkkailu. Vedenlaatu 561 vuosina 2000-2004. Vantaanjoen ja Helsingin seudun vesienhoitoyhdistys, Report 56/2005, Helsinki

562 Vahtera H, Männynsalo J (2018) Vantaanjoen yhteistarkkailu - Vedenlaatu 2017. Vantaanjoen ja 563 Helsingin seudun vesienhoitoyhdistys, Report 11/2018, Helsinki

564 Vantaanjoki-toimikunta (1985) Vantaanjoki-toimikunnan mietintö. Ympäristöministeriö, Helsinki

565 Vesistönsuojelukomitea (1958) Vesistönsuojelukomitean mietintö, 13. Kulkulaitosten ja yleisten töiden 566 ministeriö, Helsinki

567 VHVSY (2017) http://www.vhvsy.fi/sivut/virkistyskaytto. Accessed 1 Feb 2017

568 Wallis PJ, Ison RL (2011) Appreciating institutional complexity in water governance dynamics: a case 569 from the Murray-Darling Basin, Australia. Water Resour Manag 25(15): 4081-4097

570 Winiwarter V, Knoll M (2007) Umweltgeschichte: Eine Einführung. Böhlau Verlag, Köln 
571 Wardropper CB, Chang C, Rissman AR (2015) Fragmented water quality governance: constraints to

572 spatial targeting for nutrient reduction in a Midwestern USA watershed. Landsc Urban Plan 137: 64-75

573 Wolfram M (2016) Conceptualizing urban transformative capacity: A framework for research and policy.

574 Cities 51: 121-130

575 Wright SA, Jacobsen BH (2011) Participation in the implementation of the Water Framework Directive

576 in Denmark: The prospects for active involvement. Water policy 13(2): 232-249

577 


\begin{tabular}{ll} 
Component & Description \\
\hline $\begin{array}{l}\text { C1: Inclusive and multiform } \\
\text { governance }\end{array}$ & $\begin{array}{l}\text { C1 includes participatory governance, multimodality of governance forms and } \\
\text { actor networks and presence and efficiency of intermediary organisations }\end{array}$ \\
C2: Transformative leadership & $\begin{array}{l}\text { C2 is socially embedded and should be polycentric, inclusive and play } \\
\text { translational role between communities, societal groups and discourses }\end{array}$ \\
$\begin{array}{l}\text { C3: Empowered } \\
\begin{array}{l}\text { autonomous communities } \\
\text { practice }\end{array}\end{array} \quad \begin{array}{l}\text { C3 presupposes strong human agency, communities with access to resources, } \\
\text { autonomy and environment for them to form associations and coalitions based } \\
\text { on shared experiences and concerns in order to articulate common needs and } \\
\text { form responses }\end{array}$
\end{tabular}

C4: System awareness and C4 is necessary in transformation process in order to ensure the understanding memory among stakeholders of lock-ins, path dependencies and interactions. C4 needs a created and sustained shared knowledge network

C5: Urban sustainability C5 presupposes creating a shared vision of the targets and paths in foresight transformation process as well as potential scenarios

C6: Diverse community-based C6 includes practical experimentation that is necessary for acquiring experimentation with disruptive transformational knowledge and possibility of scaling up radical solutions solutions

C7: Innovation embedding and coupling

C8: Reflexivity and social learning

C9: Working across agency levels

C10: Working across administrative, geographical and political levels/scales
C7 includes space and context for the innovations to be embedded into routines, institutions, legal norms and practices

C8 relates to feedback loops, social learning and assessment to create reflexivity routines in order to critically question progress and manage new transformational knowledge

C9 presupposes developing capacity in working across different agency levels such as individuals, organisations, institutions, networks and whole society

C10 needs to be developed given the multi-scalar and multi-sectoral nature of governance and actors involved 
Table 2. The manifestations of transformative capacity in our data and the identified connections to other

582 components of capacity. Only the most evident connections are listed. Desired changes in future capacity are 583 marked with italics and connections to other components are not given to them. WPA refers to Water Protection

584 Association.

\begin{tabular}{llll}
\hline $\begin{array}{l}\text { Component of } \\
\text { capacity }\end{array}$ & transformative & $\begin{array}{l}\text { Description/ manifestation in data in regard to } \\
\text { different transformations (T) and potential future } \\
\text { transformation (TF). }\end{array}$ & $\begin{array}{l}\text { Identified connections } \\
\text { to other components }\end{array}$ \\
\hline $\begin{array}{l}\text { C1: inclusive } \\
\text { governance }\end{array}$ & and multiform & Foundation of WPA (T1) & $\begin{array}{l}\text { Required } \\
\text { contributed positively to } \\
\text { C4 and C5 }\end{array}$ \\
& & & Enabled C2 and C7 \\
& & Federation of municipalities (T2) & $\begin{array}{l}\text { Required C2, enhanced } \\
\text { C3 and C5 }\end{array}$ \\
& & &
\end{tabular}

More inclusive and participatory governance (TF)

C2: transformative leadership $\quad$ Leadership of Helsinki Waterworks within the WPA Enabled C1 (T1)

Federation of municipalities (T2)

Required C1, enabled C7

Work toward the acceptance of a new goal and the Enabled C1 creation of a new cooperative meeting system (T3).

C3: empowered and autonomous Planning with new stakeholders (T2) communities of practice

Public participation initiatives (T2)

Active NGOs and local activists (T3)

Broader acknowledgement of the vulnerability of the ecosystem (T1 and T2)

Broader recognition of the ecological values of the Enabled C3 and C5 river valley (T3)

C5: urban sustainability foresight

WPA as knowledge producer (T1)

Technical collaboration between Cities of Helsinki Required C10 and Vantaa (T1)

Alternative collective visions of future (T2)

Broader participation in planning (T2)

Natura 2000 network contributed to understanding of river values (T2)
Enhanced C1, C5 and C7

Enhanced C1, C5 and C9

Enhanced C1, C5 and C9

Identified as a basis for the other capacity

Required $\mathrm{C}$, enhanced C4

Enabled C3 and C7

Interacted with $\mathrm{C}$, enabled C9

Required C4 and C10, enabled C9 
Changes in values and collective visions toward greener future $(T F)$.

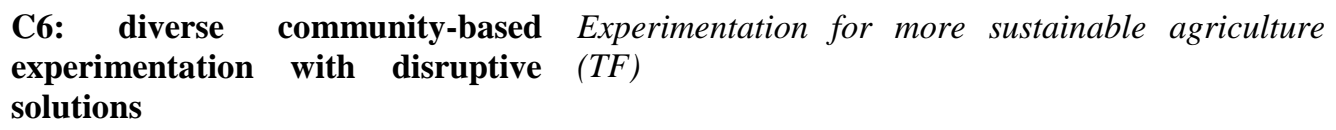

Investments in infrastructure, resources for Federation Required C1-5 of Municipalities, and new projects with new funding (T2)

$\begin{array}{lll}\text { C9: working across agency levels } & \text { Locally engaging restoration (T2) } & \text { Reciprocity with C1 and } \\ \text { C3 }\end{array}$

Diverse set of actors from individuals to institutions Reciprocity with $\mathrm{C} 1$ and (T3)

\section{C3}

Obliged C7, enabled C2 and $\mathrm{C} 5$ administrative, geographical and political levels/scales
National legislation, like Water Act (T1)

Administrative co-operation between municipalities (T1 and T2)

Natura 2000 network (T2)

Working across administrative levels and reinforcement of basin-scale governance (TF) 


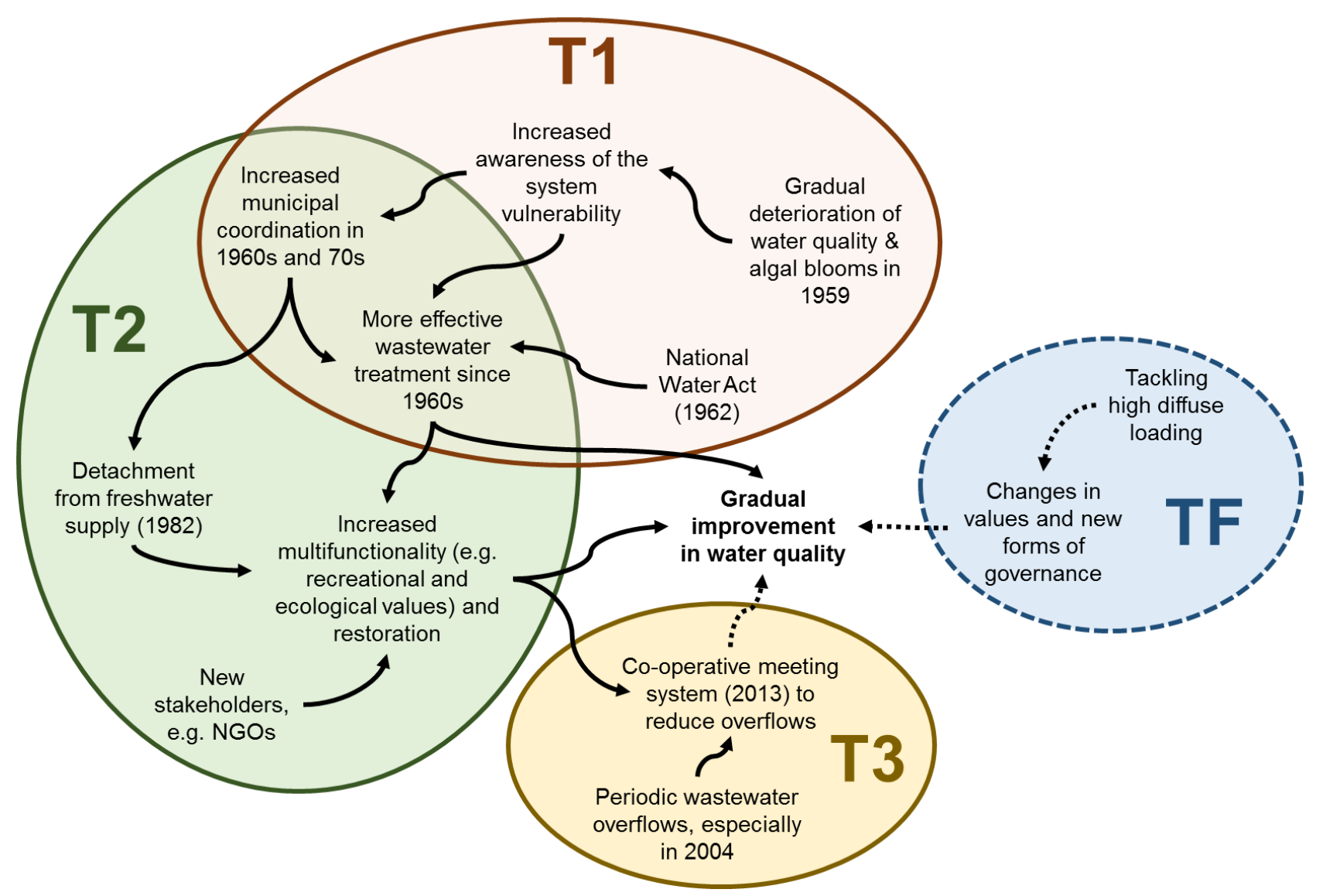

590 Figure 1. Simplified temporal flow of the causes and consequences of the different transformations: awareness

591 transformation (T1), river detachment from water supply and sewerage (T2), wastewater overflow

592 transformation (T3), and potential future transformations (TF). Potential future linkages are shown with

593 dashed lines, while already happened linkages are shown with full lines. 